\title{
Cytoplasmic Diversity Studies in Sunflower (Helianthus annuus L.): A Review
}

\author{
S.V. Yamgar ${ }^{1 *}$, P.U. Dhone ${ }^{1}$, S.M. Pathare ${ }^{2}$ and G.R. Karande ${ }^{3}$ \\ ${ }^{I}$ Department of Agricultural Botany, MPKV, Rahuri, Maharashtra, India \\ ${ }^{2}$ Department of Agricultural Botany, PDKV, Akola, Maharashtra, India \\ ${ }^{3}$ Department of Agricultural Botany, VNMKV, Parbhani, Maharashtra, India \\ *Corresponding author
}

\begin{abstract}
A B S T R A C T
\end{abstract}
\section{Keywords}

Sunflower,

Cytoplasmic diversity, Male sterility

\section{Article Info}

Accepted:

04 January 2018

Available Online:

10 February 2018
Sunflower is the fourth most important oilseed crop in the world after soybean, Rapeseedmustard and groundnut. It had 20 genera and 400 subspecies. Commercial cultivation of sunflower was started in India during 1972. In India, first ever sunflower hybrid developed by Seetharam (1980), the sunflower hybrids development is based on new sources of cytoplasmic male sterility (CMS). So far single source of cytoplasm PET-1 has been exploited extensively for hybrid $\left(\mathrm{F}_{1}\right)$ production in sunflower. PET1 or French cytoplasm, which was derived from an interspecific cross between $H$. petiolaris and H. annuus. The CMS sources ARG-1 and ARG-3 have been produced by interspecific hybridization of the annual species. However several CMS backgrounds have been developed by interspecific and intraspecific crosses which resulted in more than $72 \mathrm{CMS}$ sources. Nuclear male sterility in Sunflower is governed by individual recessive gene pair. In PET-1 cytoplasm is controlled by one dominant gene. Partial restoration of fertility observed in many source indicating presence of modifier gene PET-1 (ARM 243A) from H. Petiolaris.

\section{Introduction}

Sunflower (Helianthus annuus L.), a member of the family Asteraceae, native to Southern part of USA and Mexico. It is the fourth most important oilseed crop in the world after soybean, Rapeseed-mustard and groundnut. It is extensively grown in Russia, Ukraine, Argentina, Rominia, China, Bulgaria, Spain, Kazakistan and India. It is taking prime position in the oilseed economy both at global and national level. It is a rich source of edible oil (40 to 45\%) and is considered as good quality oil from health point of view, due to high concentration of polyunsaturated fatty acids (55 to $60 \%$ linoleic acid, 25 to $30 \%$ oleic acid), which are known to reduce the risk of coronary disease by reducing the cholesterol in blood plasma. The importance of sunflower as an oilseed crop in India is of very recent origin and date backs to three decades. But its contribution towards attaining self- sufficiency in edible oil as well as to "yellow revolution" in the country is noteworthy (MangalaRai, 2002). Cultivated sunflower is an herbaceous annual, growing to height of $50-300 \mathrm{~cm}$. The stem is branched or unbranched. Leaves 
usually opposite at top where a whorled phyllotoxy develops. Leaves vary in size, shape, hairyness and length of petiole. The inflorescence is a head which consists of two types of flower.viz ray florets and disc florets. Ray florets are sterile and form outer whorl of head while disc florets are fertile hermaphrodite flower with inferior ovary. The sepals are modified into two papus scales and five petals united to form corolla tube. The five anthers are fused to form anther tube. Stigma is bilobed. The pollen grains are viable for $12 \mathrm{hr}$ and stigma become receptive up to $20 \mathrm{hr}$.

Generally sunflower shows a phenomenon of heliotropism Sunflower had 20 genera and 400 subspecies. Among oil seed crop 3th in area and production.40-50 \%oil (55-60\% lineoic acid and 25-30\% oleic acid) highly cross pollinated. Commercial cultivation of sunflower was started in India during 1972. In India, first ever sunflower hybrid developed by Seetharam (1980), gave a fillip and renewed the interest in crop. Hybrids are preferred over varietal populations because of their high productivity in terms of seed and oil yield. Hybrids are more productive, uniform and also respond to higher level of fertilizer application and irrigation. In view of these advantages, the coverage of area is more under hybrids and it is around 95 percent

\section{Need of diverse cytoplasm}

The discovery of cytoplasmic male sterility in sunflower given by Leclercq (1969). It was produced cross between Helianthus petiolaris Nutt. with cultivated Helianthus annuus L. and designted as PET-1. Furthermore, fertility restoration gene were identified by Kinman, (1970), Leclercq (1971) and Enns, (1972). It has facilitated to commercial hybrid seed production. Mostly in present day sunflower hybrids utilize only PET-1 source of cytoplasm for all hybrid production. It may lead to high degree of genetic vulnerability to biotic and abiotic stress. There is need to discover new cytoplasm for hybrid production. The first CMS reported in sunflower in 1969 , as many as 72 CMS sources have been identified (Serieys, 2005). The studies on genetic divergence are important for breeding aiming to obtain hybrid cultivars, so that crosses can be made among genetically divergent lines which have contrasting and complementary. The utilization of different cytoplasmic backgrounds in hybrid development will improve general variability of the sunflower and lessen the threats of epiphytotics. There are several experiments to estimate the influence of the cytoplasmic effect on important agronomic traits. It has been conducted before their introgression into commercial breeding programs to estimate the information on nature and magnitude of variability present in a population due to genetic and non-genetic components which is important prerequisite for systematic breeding programme. The CMS sources ARG-1 and ARG-3 have been produced by interspecific hybridization of the annual species Helianthus argophyllus used as the female parent and the cultivated sunflower used as the male parent. The cytoplasmic sterility has been maintained by a large number of varieties self-pollinated lines. This indicates that the new type of sterility can bê utilized as a CMS source in developing sunflower hybrids. Some lines have been identified as possible rcstorers of the two CMS types. It is of special interest to reduce the potential risk of vulnerability to pathogens and to increase genetic diversity.

\section{Taxonomy of genus helianthus}

The sunflower belongs to the genus Helianthus, Asteraceae family. Heiser et al., (1969) described 66 species, 48 from North America and 18 from South America. The former group comprises 12 annual and 37 perennial species classified into 3 sections and 
7 series the authors classified the 49 species into 4 sections and 6 series. Section Helianthus covers 11 annual species including the cultivated sunflower (Schilling and Heiser, 1981). Sections are 1. Helianthus 2. Agrestis 3. Ciliares 4. Divaricati.

\section{Genome}

Cultivated sunflower $(2 n=34)$ was determined by Tahara (1915) He reported that basic chromosome number of Helianthus is $n=17$, the genus is a polyploidy include diploid $(2 n=2 x=34)$, tetraploid $(2 n=4 x=68)$ and hexaploid $(2 \mathrm{n}=6 \mathrm{x}=102)$ species. Total number of Helianthus species is 52 out of them 14 Diploid annuals $(2 n=2 x=34)$, Twenty seven were Diploid perennials $(2 n=2 x=34)$, Tetraploid perennials $(2 n=4 x=68)$ are four only. Hexaploid perennials $(2 n=6 x=102)$ were seven. There are two Mixaploid perennials $(2 n=2 x=34, \quad 4 x=68)$ and two Mixaploid annuals $(2 \mathrm{n}=4 \mathrm{x}=68,6 \mathrm{x}=102)$

\section{Male sterility in sunflower}

Sunflower crop have two types of male sterility

\section{Nuclear male sterility}

Nuclear male sterility in Sunflower governed by individual recessive gene pair, A number of genes determine this traits differ (ms1 to ms5, Vranceanu, 1970; ms6 to ms9, Jan, 1992). AS 110 and AS-116 contain ms 1 gene which have 2-4 univalent at diplotene-dikanisis cause asynapsis (Paun, 1974). 4-6\% pollen grains stained with acetocramine in which $75 \%$ are normal but lacking spiny exine.

\section{Cytoplasmic male sterility}

The discovery of first CMS in helianthus made possible to development hybrid sunflower. There is numerous CMS sources until 72 (Series, 2005). CMS in sunflower mostly alloplasmic which describe male sterility resulting from interspecific and intergeneric cross (Pearson, 1981). Incapability between nucleus and cytoplasm Many of them have restorer gene but still not in commercial hybridization.

\section{Application of wild species in sunflower breeding}

Diploid perennial sunflower are resistance to diseases. These are Helianthus giganteus and Helianthus maximiliani.

The Helianthus occidentalis and Helianthus tuberosus are highly resistance to alternaria blight. Helianthus pauciflorus is resistance to disease and high oil content. The sunflower species Helianthus resinosus is high content of oleic acid and high oil content. There is cross ability between diploid wild and cultivated species, but using embryo culture these species are crossed successfully (Krauter et al., 1991).

Tetraploid species Helianthus hirsutus, Helianthus decapetalus, Helianthus. laevigatus and Helianthus strumosus successfully crossed with the cultivated sunflower.

Georgieva-Todorova et al., (1979), Georgieva-Todorova (1984) and Atlagić (1994)

Lines in the 1000 series are derived from crosses between Helianthus argophyllus and sunflower, 2000 series from Helianthus petiolaris and sunflower, 3000 series from Helianthus annuus (wild) and sunflower, 4000 series from trispecific cross involving Helianthus argophyllus, Helianthus annuиs (wild) and sunflower, 5000 from sunflower and Helianthus debilis. 


\section{Genome}

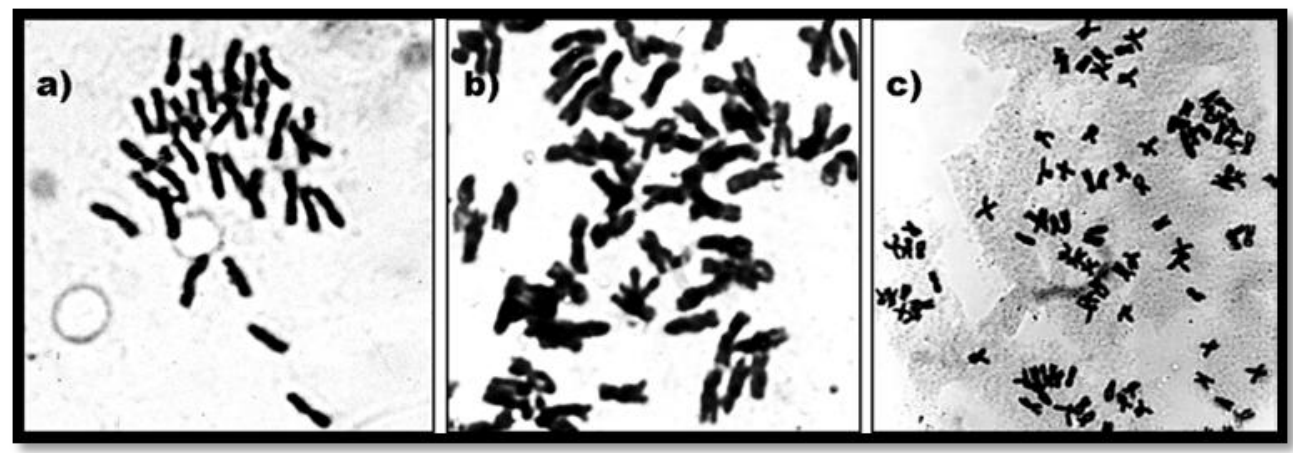

Polyploidy in the genus Helianthus: a) H. annuus, $2 n=34$, b) H. hirsutus, $2 n=68$ c) H. rigidus, $2 n=102$

Promising material developed from diploid species

\begin{tabular}{|c|c|c|}
\hline Sr.No & Trait & Lines developed \\
\hline 1 & Rust & $1089,2011,2032$ \\
\hline 2 & Alternaria (tolerance) & 2036 \\
\hline 3 & $\begin{array}{l}\text { Alternaria } \\
\text { (susceptible- useful for genetic studies) }\end{array}$ & 2046,3035 \\
\hline 4 & cms cytoplasm & Arg. \\
\hline 5 & Restorers for Arg cyto & $P 73,2026,5017,5016$ \\
\hline 6 & Superior inbreds/conversion & 48 out of 80 \\
\hline 7 & Drought endurance & $1066,2005,2036,4091$ \\
\hline 8 & $\begin{array}{l}\text { Phenotypic variants(Susc but High yield) } \\
\text { Agronomically superior line White pollen, } \\
\text { double heads from crosses involving } \\
\text { sunflower and } H \text {. divaricatus }\end{array}$ & 2046,4005 \\
\hline
\end{tabular}

\section{Identification of maintainer and restorer}

In sunflower, hybrids are superior over openpollinated cultivars in terms of yield, selffertility and resistance to diseases (Miller, 1987). Risk to commercial hybrid is from biotic and abiotic stresses because of narrowing genetic base. An attempt was done for this limitation in which 12 diverse cms lines with 4 resistance source PEF from $H$. petiolaris sub. species. fallax, CMS I from $H$. lenticularis, $f$ PET-2 from $H$. petiolaris and the traditional cytoplasmic source PET-1 by crossing with 12 newly Inbred developed lines. Availably of fertility restoration for new cms source is limited. In PET-1 cytoplasm is controlled by one dominant gene. (Dominguez-Gimenez and Fick, 1975). Partial restoration of fertility observed in many source indicating presence of modifier gene. PET-1 (ARM 243A) from H. petiolaris, CMS PEF (FMS 850 A) from $H$. petiolaris sp. fallax and CMS I (IMS 850 A) from $H$. lenticularis were crossed with 4 inbreed lines. ARM 243A x 95-C1, IMS 850A x GP-322-1 and FMS 850A x LTRR-5 segregated in the ratio of 9 fertile: 7 sterile. Indicating the presence of two complementary dominant genes were responsible for fertility restoration. Neither of gene alone gives restoration. In the cross ARM 243A x 3376R (PET-1 source), a 3:1 segregation for $\mathrm{f} \& \mathrm{~s}$ 
was observed indicating single dominant gene for fertility restoration (Leclercq, 1971; Kural and Miller, 1992). The fertility in ARM 243A was reported by a single dominant gene contributed from 3376R and two complementary genes present in 95-C1.

These findings indicated existence of diverse mechanism for fertility restoration. Concluded that the fertility restoration was controlled by single or two dominant genes depending on the restorers involved and CMS lines used. Further studies are needed to know the precise mechanism of fertility restoration using different CMS sources and fertility restorers.

\section{Cytoplasmic male sterility sources}

\section{Spontaneously occurring}

Mutant male sterile cytoplasm arises spontaneously in low frequency. Mutant cytoplasm have been isolated in sunflower from PET-1 containing two polymeric gene $\mathrm{Rf}_{1}$ and $\mathrm{Rf}_{2}$ genes These mutations occur in nature spontaneously due to subjection to the naturally occurring agents like electric current, injuries due to atomic rays and particles, pests and disease, temperature, and chemicals, etc.

\section{Interspecific cross}

It is the hybridization between two species of same genus. It is also called intrageneric hybridization. In sunflower developed cytoplasm male sterile line through interspecific crossing was PET1 or French cytoplasm, which was derived from an interspecific cross between $H$. petiolaris and H. annuus (Leclercq, 1969).

\section{Chemically induced male sterility}

Many chemicals used for inducing male sterility in crops these chemicals are known as male gamatocide. First report of chemically induced male sterility was that by Moore in 1950. Many gamatocides like ethrel, maleic hydroxide, FW-450 are used for inducing the male sterility.

\section{Feature opportunity}

Addition of molecular tools to mine the available genetic diversity.

Opportunity to move exotic genes with more precision and efficiency.

Currently bioinformatics is the bottleneck for complete exploitation of genetic resources information.

\section{Future challenges}

Genetic resources-Global political problems.

Decreased opportunity for germplasm exchange

Decline in the funding and lack of commitment by countries for genetic resources

Sunflower is widely used as oilseed crop after the Soybean. In sunflower commercial hybrid is produced by using cytoplasm male sterile. The first CMS source was PET-1 developed in 1969, now day 72 CMS line were available and widely used for Commercial hybrid production. But next future prospect is to develop new cytoplasmic male sterile line with desirable genes resistance to various abiotic and biotic stresses.

\section{References}

Albert Armin, Text book of Sunflower and Production Vol.35 June 2011

Atagi, J.1990. Pollen fertility in some Helianthus wild species and their F1 
hybrids with cultivated Sunflower, Helia 13:47-54

Bhattacharjee, R., 1996, Heterosis and combining ability of converted female and restorer lines of sunflower. $M . S c$ (Agri.) Thesis, Univ. Agric.

Enns, H., Dorrel, D.G. and Hoes J, A., 1970. Sunflower research a progress report. In: Proc. of the 4th Int. Sunflower Conference, pp-162-167, 23-25 June 1970, Memphis USA.

Jan, C.C, 1990. In search of cytoplasmic male sterility and fertility restorer genes in wild Helianthus Species In: Proc. of Sunflower research workshop, pp-3-5, 8-9 Jan 1990, Fargo, ND, USA

Jan, C.C, 1990. In search of cytoplasmic male sterility and fertility restorer genes in wild Helianthus Species In: Proc. of Sunflower research workshop, pp-3-5, 8-9 Jan 1990, Fargo, ND, USA

Kinman, M.L, 1970. New development in USDA and state experiment station: Proc. of $4^{\text {th }}$ international conference, pp-181-183, Memphis, USA
Leclercq, P., 1969. Line sterile cytoplasmique chezk tournesol. Ann. Amelior Planta, 12: 99- 106.

Leclercq, P., 1970. Sterile male cytoplasmique da tournsal Ann. Ann. Amelior Planta, 19(2): 99- 106.

Mangala Rai, 2002. Oilseeds in India. Andhra Pradesh Agric. Reg. Res. J., pp.13-15.

Marinkovic, R., Mihaljeevic, M. and Joksimoic, J., 1993. Genetic diversity of sunflower (Helianthus annuи L.) varietal populations assessed by cluster analysis. In: Proc. of the 13th Int. Sunflower Conference, Pisa, Italy, 7-11 September 1992, 2: 1135-1140

Ortis, L., Nestures, G., Frutos, E. and Machado, N., 2005. Combining ability analysis for agronomic traits in sunflower (Helianthus annus). Helia, 28: $125-134$.

Seetharam, A., 1980. Hybrid sunflowers. Indian Farming, 29: 15

Seetharam, A., Kusumakumari, P., Patil, N. M. and Singagi, S. S., 1977. Performance of hybrids of sunflower produced by means of cytoplasmic male sterility. SABRAO Journal, 9: 51-55

\section{How to cite this article:}

Yamgar, S.V., P.U. Dhone, S.M. Pathare and Karande, G.R. 2018. Cytoplasmic Diversity Studies in Sunflower (Helianthus annuus L.): A Review. Int.J.Curr.Microbiol.App.Sci. 7(02): 36-41. doi: https://doi.org/10.20546/ijcmas.2018.702.006 